\title{
Księgozbiór rodziny Żabów ze Zbylitowskiej Góry w zbiorach Miejskiej Biblioteki Publicznej im. Juliusza Słowackiego w Tarnowie
}

Przed drugą wojną światową ziemię tarnowską zamieszkiwały liczne rodziny szlacheckie, wśród których napotykamy ród Żabów, wiodących swe początki z Litwy i pieczętujących się herbem Kościesza. Linia zamieszkująca w drugiej połowie XIX wieku Zbylitowską Górę wywodziła się od Napoleona Feliksa Żaby. Rodzinie tej, posiadającej tradycje wojskowe, poświecono liczne artykuły i publikacje, głównie skupiające uwagę na wnuku Napoleona Feliksa Żaby, generale Romanie Żabe ${ }^{1}$ oraz wspomnieniach ostatniego właściciela Zbylitowskiej Góry, inż. Franciszka Żaby². W dotychczasowych opracowaniach nie znalazły się jednak informacje o bibliotece, jaką zgromadzili w dworze kolejni członkowie rodziny. Nie były też (do 2013 r.) prowadzone badania nad zachowanymi książkami z tejże biblioteki, które przechowywane są obecnie w Miejskiej Bibliotece Publicznej im. Juliusza Słowackiego w Tarnowie. Badania bibliologiczne i krytyka dostępnych źródeł pozwoliły poznać losy księgozbioru ze Zbylitowskiej Góry.

\section{Rys biograficzny rodziny Żabów z Zbylitowskiej Góry}

Napoleon Feliks Żaba (1805-1885) urodził się w Krasławiu na Witebszczyźnie jako syn Dominika Żaby i Anny Hołownia Ostrowieckiej ${ }^{3}$. Według

1 M.in. P. S. Szlezynger, Kilka uwag na marginesie wspomnień generała Romana Żaby ze Zbylitowskiej Góry, „Rocznik Tarnowski”, 2003/2004, s. 171-228; Nieznane pamiętniki generała Romana Żaby: przyczynek do historii wojskowości polskiej $w$ dwudziestoleciu międzywojennym, oprac. P. Szlezynger, ,Zeszyt Naukowy Muzeum Wojska w Białymstoku", 17:2004, s. 144-154.

2 F. F. Żaba, Gawędy Franciszka Żaby o dawnych czasach, „Zeszyty Wojnickie”, 2006, nr 2, s. 28-41; nr 3, s. 31-41.

3 Bratem N. F. Żaby był August Żaba (1801-1894), orientalista polski i dyplomata w służbie rosyjskiej. Jako pierwszy Polak prowadził on badania nad zwyczajami Kurdów; wyniki opublikował po francusku w pracy Receueil des notices et récits de la littérature et 
niepotwierdzonych informacji studiował na Uniwersytecie Wileńskim, natomiast pewne jest, że w 1823 r. wstapił do Szkoły Podchorążych w Warszawie $^{4}$. Wraz z dwoma innymi kadetami: Józefem Godebskim i Kamilem Mochnackim w 1827 r. zaczął wydawać pismo „Chwila Spoczynku”, które zawierało przegląd literatury polskiej, opowiadania, wiersze i artykuły o modzie paryskiej. Z powodu krytycznych uwag, z jakimi spotkało się to wydawnictwo, ukazało się jedynie dziewięć numerów ${ }^{5}$.

Po upadku powstania listopadowego N. F. Żaba wyemigrował najpierw do Francji ${ }^{6}$, gdzie w kwietniu 1832 r. został aresztowany za udział w spisku mającym na celu intronizację Napoleona II ${ }^{7}$. Uniewinniony, wyjechał do Anglii i osiadł w Edynburgu, gdzie w 1833 r. wraz z Piotrem Falkenhagen-Zaleskim wydawał w języku angielskim perdiodyk „The Polish Exile”, traktujący o historii, geografii oraz literaturze polskiej. Ostatni, dwunasty, numer czasopisma ukazał się we wrześniu tego samego roku8. W 1834 r. N. F. Żaba został członkiem szkockiej loży masonów Connongate Kilwinning w Edynburgu' ${ }^{9}$. Żaba był też kontynuatorem i propagatorem metody mnemotechnicznej ułatwiającej naukę historii, literatury i statystyki wynalezionej przez Antoniego Jaźwińskiego, a rozwiniętej i udoskonalonej przez gen. Józefa Bema. W latach czterdziestych XIX wieku Żaba uprościł i spopularyzował tę nową metodę nauczania. W oparciu o nią z powodzeniem prowadził wykłady w szkołach w Madrycie, Lizbonie, Paryżu oraz publikował liczne artykuły i książki na jej temat ${ }^{10}$. Ponadto był autorem 20 pism zawierających teksty publicystyczne na temat historii i literatury polskiej oraz poezje. Tłumaczył także z języka rosyjskiego utwory Aleksandra Puszkina ${ }^{11}$. Po roku $1860 \mathrm{z}$ ramienia Hotelu Lambert organizował w Londy-

des tribus du Kourdistan (1861). Ponadto opracował pierwszy słownik francusko-kurdyjski (1879). Zob <http://www.kurdishstudies.pl/?pl_august-kosciesza-zaba,33> (1 II 2015).

4 I. Homola-Skapska, ,, The Polish Exile”.". Polskie czasopismo anglojęzyczne i jego redaktorzy (1833), „Rocznik Historii Prasy Polskiej”, 12:2009, z. 1, s. 12.

5 Tamże, s. 12.

6 Julian Ursyn Niemcewicz, niechętnie do N. F. Żaby nastawiony, utrzymywał, że wstąpił on do armii rosyjskiej, z której później zdezerterował. J. U. Niemcewicz, Pamiętniki. Dziennik pobytu za granica od dnia 21 VII 1831 do 20 V 1841, t. 1, Poznań 1876, s. 575.

Żaba Napoleon Feliks, [w:] Stownik Biograficzny Historii Polski, t. 2, Wrocław 2005, s. 1748.

8 I. Homola-Skapska, ,, The Polish Exile”..., s. 19.

9 L. Hass, Wolnomularstwo w Europie środkowo-wschodniej w XVIII i XIX wieku, Wrocław 1982, s. 332.

10 N. F. Żaba wydał w sumie osiem publikacji książkowych na temat wspomnianej metody nauczania historii. Książki te opublikowano w językach: polskim, angielskim, francuskim, a także czeskim.

11 Marian Toporowski w swej pracy na temat m.in. polskich przekładów Puszkina podaje dwa tłumaczenia N. F. Żaby, których zarazem nie ocenia dobrze: Fontanna 
nie mityngi i odczyty o Polsce ${ }^{12}$. Po 1863 r. działał w Lidze Narodowej dla Niepodległości Polski; odbył podróże do Stanów Zjednoczonych, Brazylii, Australii, Tasmanii i Nowej Zelandii ${ }^{13}$, a także do Azji i Japonii ${ }^{14}$. Był profesorem i rektorem uniwersytetu w Buenos Aires, gdzie wykładał historię i języki obce ${ }^{15}$. W Portugalii otrzymał Order Chrystusa i tytuł hrabiowski ${ }^{16}$.

W 1881 r. N. F. Żaba osiadł w Zbylitowskiej Górze u syna Stanisława. Podejmował podróże po kraju i wygłaszał odczyty z okazji rocznic narodowych bądź przybliżał kraje, które zwiedził ${ }^{17}$. Dochody z prelekcji przeznaczał zawsze na rzecz instytucji dobroczynnych ${ }^{18}$. Zmarł w $1885 \mathrm{r}$. w Zbylitowskiej Górze i został pochowany na miejscowym cmentarzu.

W 1830 r. N. F. Żaba poślubił szkocką szlachciankę Annę MacLeod ${ }^{19}$ (1803-1863), córkę ppłk. Johna MacLeod i Joan Paton. Anna i Napoleon mieli jednego syna Stanisława (1838-1919) ${ }^{20}$.

Stanisław Żaba kształcił się w Anglii oraz Francji. W Tarant odbył studia rolnicze, w 1854 r. zwyczajowo ojciec kupił mu stopień podporucznika angielskiego pułku East-Kent, w efekcie czego Żaba służył m.in. na Krymie, Malcie i Gibraltarze ${ }^{21}$. W 1862 r. na zaproszenie hrabiego Jana Stadnickiego z Wielkiej Wsi ${ }^{22}$ przyjechał do Galicji, gdzie poślubił Marię Ewę hr. Moszczeńską herbu Nałęcz (1840-1916) i zamieszkał w Zbylitowskiej Górze, która należała do rodziny Moszczeńskich ${ }^{23}$. Stanisław i Maria mieli pięcioro dzieci: córki Celinę (1865-1961) oraz bliźniacz-

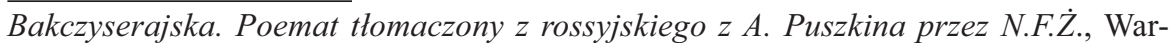
szawa 1828; oraz Jeniec Kaukazu. Poemat w dwóch częściach tłomaczony z języka rossyjskiego A. Puszkina $i$ wiersz oryginalny Wygnaniec świata $w$ dwóch cześsiach, Warszawa 1828 (M. Toporowski, Puszkin w Polsce zarys bibliograficzno-literacki, Kraków 1950).

${ }^{12}$ I. Homola-Skapska, ,, The Polish Exile”,..., s. 21.

13 Kronika Geograficzna, „Wędrowiec”, 1881, nr 238, s. 45.

14 F. F. Żaba, Gawędy..., s. 39.

15 E. Rohozińska, Żaba Napoleon Feliks, [w:] Literatura Polska. Przewodnik encyklopedyczny, Warszawa 1985, s. 694.

16 F. F. Żaba, Gawędy..., s. 40.

${ }^{17}$ Kronika Geograficzna, „Wędrowiec”, 1881, nr. 238, s. 45.

18 Wrocław, Zakład Narodowy im. Ossolińskich, rps 12424, Papiery Bełzów, s. 433435; rps 5985 Zbiór korespondencji Wiktora hr. Baworowskiego, s. 67-70; rps 5918 Korespondencja Henryka Schmitta z lat 1845-1882, s. 189.

19 Anna Davis z MacLeod była wdowa, N. F. Żaba adoptował jej córkę z pierwszego małżeństwa - Annę Davis.

${ }^{20}$ T. Żychliński, Złota księga szlachty polskiej, t. 4, Poznań 1884, s. 455.

21 R. Żaba, Wspomnienia z lat ubiegtych (od 1864 do 1937): generat Roman Żaba i jego czasy, Kraków 2009, s. 9-10.

${ }^{22}$ Księgozbiór podworski należący do rodziny Stadnickich z Wielkiej Wsi również znajduje się w MBP w Tarnowie.

${ }_{23}$ T. Żychliński, Złota księga szlachty polskiej..., s. 455. 
ki - Marię (1866-1959) i Julię (1866-1940), a także synów: Romana (1864-1945), Franciszka (1868-1942) i Borysa²4 (1880-1950).

Stanisław, wystapiwszy z wojska angielskiego w 1863 r., zajął się zarządzaniem majątkiem ziemskim. Był też inicjatorem utworzenia w Tarnowie filii Krakowskiego Galicyjskiego Banku dla Rozwoju Handlu i Przemysłu ${ }^{25}$, a w latach 1887-1891 - członkiem komisji rewizyjnej Towarzystwa Ziemskiego Kredytowego we Lwowie ${ }^{26}$. W 1877 r. przeniósł się do Paryża, gdzie wraz ze Stanisławem Juliuszem hr. Ostrorogiem rozbudował sieć zakładów fotograficznych pod nazwą „Walery”27. W 1883 r. wspólnie otworzył studia fotograficzne w Londynie. S. Żaba należał do licznych klubów angielskich.

W 1911 r. państwo Żabowie podzielili swój majątek między synów (Romanowi przypadł folwark Zawodzie oraz Szczepanowice, Borysowi - Wielkopole Moszczańskie, natomiast Franciszkowi - Zbylitowska Góra oraz Sieciechowo), córkom zaś zostały wypłacone kwoty po 100 tys. koron ${ }^{28}$.

Franciszek Kenneth Żaba (1868-1942) był prezesem Towarzystwa Kredytowego Ziemskiego we Lwowie ${ }^{29}$. W latach młodości uczęszczał do Akademii Handlowej w Wiedniu ${ }^{30}$. Następnie przez rok praktykował w Anglii, a po powrocie do Wiednia wstapił do Central-Boden-CreditBank $^{31}$. Ożeniony w 1896 r. z bogatą Austriaczką Elizabeth Hutter (18721946) $)^{32}$, nie doczekał się potomstwa.

Borys Żaba ${ }^{33}$ (1880-1950) uczęszczał w dzieciństwie do Gimnazjum w Kresier. Nie natrafiono na konkretne wiadomości na temat jego studiów we Lwowie ${ }^{34}$, jednak na pomniku nagrobnym Borysa widnieje tytuł profesorski ${ }^{35}$. Wiadomo jeszcze, że był zapalonym myśliwym ${ }^{36}$. Podczas pierwszej wojny światowej na prośbę matki odkupił od starszego bra-

24 Tamże.

25 R. Żaba, Wspomnienia z lat ubiegłych..., Kraków 2009, s. 10.

26 W. Ostrożyński, Galicyjskie Towarzystwo Kredytowe Ziemskie: jego powstanie i półwiekowy rozwój, Lwów 1892, s. 366.

${ }_{27}$ R. Żaba, Wspomnienia z lat ubiegtych..., s. 10.

28 Tamże, s. 11.

29 Tamże, s. 18.

30 Tamże, s. 126.

31 Tamże, s. 149.

32 Elizabeth Hutter - córka właściciela firmy Hutter i Schrantz, produkującej m.in. druty kolczaste. R. Żaba, Wspomnienia z lat ubiegłych..., s. 20.

33 Na rodzinnym pomniku nagrobnym wyryto „Stanisław Borys Żaba”, jednak $\mathrm{w}$ rodzinie używano drugiego imienia i pod nim jest najlepiej znany.

34 R. Żaba, Wspomnienia z lat ubiegłych..., s. 194.

${ }^{35}$ Prawdopodobnie chodzi o zwyczajowy tytuł profesora gimnazjum.A. Kaznowiecka, Z historii rodziny Żabów, „Zeszyty Wojnickie”, 1994, nr 5, s. 12.

${ }^{36}$ F. F. Żaba, Gawędy..., s. 31. 
ta Romana folwark w Zawodziu. Borys miał dwoje dzieci z Marią ze Schneidrów (1894-1944): Stanisława Jerzego oraz Zofię. W 1903 r. debiutował tomikiem poezji wydanym u Hermana Altenberga ${ }^{37}$. Dwa lata później wydał kolejny tom poezji ${ }^{38}$. Zmarł w Toruniu, gdzie żył i pracował po opuszczeniu żony przed drugą wojną światową ${ }^{39}$.

Roman Żaba (1864-1945) pobierał nauki w paryskim Instytucie św. Marii, a następnie w College Moyen i College Chaptall. W 1874 r. zdał egzamin z zakresu czterech klas szkoły ludowej i rozpoczął naukę w I Gimnazjum w Tarnowie ${ }^{40}$.

W sierpniu 1885 r. R. Żaba rozpoczął zawodową służbę wojskową w Cesarskiej i Królewskiej Armii ${ }^{41}$. Służbę pełnił m.in. w garnizonie Stockerau pod Wiedniem, w 7. Pułku Ułanów Arcyksięcia Franciszka Ferdynanda, wchodzacym w skład 10. Brygady Kawalerii. 31 grudnia 1916 r. mianowany został dowódcą 3. Pułku Ułanów Arcyksięcia Karola $^{42}$. Z dniem 1 listopada 1918 r. przyjęty został do Wojska Polskiego z zatwierdzeniem posiadanego stopnia pułkownika i przydzielony do Komendy 2 .Pułku Ułanów w Krakowie. Został pierwszym dowódcą i organizatorem wspomnianego oddziału, który w styczniu 1919 r. przemianowany został na 2. Pułk Szwoleżerów Rokitniańskich ${ }^{43}$. W lipcu 1919 r. objął dowództwo IV Brygady Jazdy. 10 stycznia 1920 r. mianowany został inspektorem wyszkolenia Frontu Pomorskiego i komendantem Centrum Wyszkolenia Oficerów w Grudziądzu. Od 15 marca do 25 sierpnia 1920 r. przebywał w Londynie jako szef Polskiej Misji Zakupów ${ }^{44}$. Po powrocie do kraju wyznaczony został na stanowisko zastępcy szefa Naczelnej Kontroli Wojskowej. 14 października 1920 r. zatwierdzony został $\mathrm{z}$ dniem 1 kwietnia $1920 \mathrm{r}$. w stopniu generała podporucznika ${ }^{45}$. Następnie pełnił służbę na stanowisku zastępcy Generalnego Inspektora Jazdy, gen. dyw. Tadeusza Rozwadowskiego ${ }^{46}$, a od 1 X 1921 r. do 30 V 1922 r. - za-

37 B. Żaba, Poezye, Lwów 1903. Niestety, nie spotkały się one z dobrym przyjęciem przez krytyków literackich. Literatura i Sztuka: Nowe ksiażki, „Prawda”, 1904, nr 46, s. 549.

38 B. Żaba, Poezye, t. 2, Lwów 1905.

39 A. Kaznowiecka, Z historii rodziny Żabów, „Zeszyty Wojnickie”, 1994, nr 5, s. 12.

40 R. Żaba, Wspomnienia z lat ubiegtych..., s. 50.

${ }^{41}$ W. Bałda, Generat legionistom niechętny, „Miasto i ludzie”, 2014, nr 4, s. 26

${ }^{42}$ R. Żaba, Wspomnienia z lat ubiegtych..., s. 50.

43 W. Bałda, Generat legionistom niechętny..., s. 26.

44 Tamże.

45 R. Żaba, Wspomnienia z lat ubiegtych..., s. 51.

46 R. Żaba napisał wspomnienia pt. Stary przyjaciel, które ukazały się w zbiorze tekstów poświęconych pamięci T. Rozwadowskiego: Generat Rozwadowski. Księga ku czci generała Tadeusza Jordana Rozwadowskiego w pierwsza rocznice zgonu, Kraków 1929, s. 200-202. 
stępcy dowódcy Okręgu Korpusu Nr V w Krakowie ${ }^{47}$. Z dniem 1 czerwca 1922 r. przeniesiony został w stały stan spoczynku z prawem noszenia munduru w stopniu generała porucznika. 26 października 1923 r. Prezydent RP zatwierdził go w stopniu generała dywizji ze starszeństwem z 1 czerwca 1919 r. w korpusie generałów ${ }^{48}$.

Oprócz funkcji wojskowych R. Żaba działał charytatywnie w ramach Towarzystwa Dobroczynnego im. św. Wincentego a Paulo i Towarzystwa Dobroczynnego im. ks. Piotra Skargi. Angażował się też w prace społeczno-gospodarcze organizacji Związku Ziemian i Banku Gospodarstwa Krajowego ${ }^{49}$. Po przejściu na emeryturę osiadł w Krakowie, gdzie zmarr $^{50}$.

W 1900 r. we Lwowie R. Żaba zawarł związek małżeński z Anną Oczosalską (1882-1936), która przez wiele lat pełniła funkcję prezesa Związku Sodalicji Inteligencji Żeńskiej w Polsce ${ }^{51}$. Z tego związku urodziło się troje dzieci: Olga (1901-1990) i Maria (1903-1982) - wychowanki sióstr Zgromadzenia Najświętszego Serca Jezusa w Zbylitowskiej Górze oraz Franciszek Feliks (1906-1982) ${ }^{52}$.

Franciszek Feliks Żaba uczęszczał do gimnazjum im. Adama Mickiewicza w Krakowie, a następnie studiował na Wydziale Rolnym Uniwersytetu Jagiellońskiego ${ }^{53}$. Franciszek ożenił się w 1934 r. z Ireną Malczyk (1908-1993), z którą miał trzy córki: Teresę, Annę i Martę oraz zmarłego w dzieciństwie syna Romana ${ }^{54}$. Wiosną 1939 r. objął posadę administratora gospodarstwa rolnego w Mościcach przy Zakładach Azotowych ${ }^{55}$. Podczas okupacji jako oficer AK był komendantem placówki w Mościcach ${ }^{56}$. W latach 1941-1944 m.in. z jego inicjatywy w Zakładach Azotowych funkcjonowała tajna fabryczna liga piłkarska. W rozgrywkach ligi uczestniczyli sportowcy klubu Unia Tarnów pozostający na „dwóch etatach": jawnym w fabryce i konspiracyjnym w ruchu oporu.

47 Tamże.

48 W. Bałda, Generat legionistom niechętny..., s. 26.

49 Tamże.

50 Tamże.

51 A. Żaba-Branny, Franciszek $\dot{Z} a b a<$ http://krakow.gazeta.pl/krakow/1,53181,3952 629.html> (1 II 2015).

52 Tamże.

53 F. F. Żaba, Gawędy..., s. 28.

54 Na nagrobku rodzinnym widnieje jedynie informacja o śmierci R. Żaby w 1946 r.

55 W. Szura, Tarnowscy dzialacze lowieccy - inż. Franciszek Żaba, „Łowiec Tarnowski”, 2012, nr 2, s. 34

56 F. F. Żaba, Gawędy..., s. 29. 
W lutym 1945 r. Franciszek wraz z innymi żołnierzami AK został zatrzymany i przez sześć tygodni był przetrzymywany w więzieniu w Tarnowie. W tym samym czasie w wyniku reformy rolnej Żabowie utracili dwór i majątek w Zbylitowskiej Górze ${ }^{57}$. Wypuszczony dzięki poręczeniu pracowników gospodarstwa rolnego, otrzymał zakaz osiedlenia $\mathrm{w}$ rejonie tarnowskim ${ }^{58}$. Wyjechał więc do Krakowa i objął posadę administratora (później dyrektora) Stacji Hodowli Buraka Cukrowego w Górce Narodowej ${ }^{59}$. W 1960 r. podjął pracę w Instytucie Hodowli i Aklimatyzacji Roślin w Krakowie. W instytucie prowadził hodowlę żyta tetraploidalnego. Równocześnie rozpoczął pracę dydaktyczną na Akademii Rolniczej wykładając łowiectwo ${ }^{60}$. W 1968 r., zaproszony przez osiadłego w Sao Paulo przyjaciela, księcia Romana Sanguszkę z Gumnisk, wyjechał wraz z żoną do Brazylii, gdzie przebywał blisko dziesięć lat ${ }^{61}$. Po powrocie podjął pracę w Państwowym Gospodarstwie Rolnym w Urbanowiczach. Działalność zawodową zakończył w 1980 r. i skoncentrował się na pracy naukowej i pisaniu wspomnień zatytułowanych Gawędy z córkami ${ }^{62}$. Należał do Korporacji Akademickiej Corolla.

Rodzina Żabów utrzymywała liczne kontakty towarzyskie nie tylko z wojskowymi, z którymi mieli kontakt poszczególni męscy przedstawiciele rodziny podczas swojej służby wojskowej, ale i z lokalnym ziemiaństwem zamieszkującym ziemię tarnowską, brzeską oraz dąbrowską. Wśród nich warto wymienić Stoińskich z Otfinowa, Jordanów z Zamościa koło Wojnicza, Konopków z Brnia, Stadnickich z Wielkiej Wsi, Sanguszków z Gumnisk ${ }^{63}$.

\section{Losy majątku i biblioteki Żabów}

Zespół zachowanych zabudowań dworskich w Zbylitowskiej Górze tworzą: budynek dworski, oranżeria, oficyna oraz park. Istniejący obecnie dwór wybudowano po 1830 r. na zlecenie Franciszka Moszczeńskiego w miejscu wcześniejszego, drewnianego, który spłonął. Za projektan-

${ }^{57}$ W. Szura, Tarnowscy działacze łowieccy - inż. Franciszek Żaba..., s. 34

${ }^{58}$ F. F. Żaba, Gawędy..., s. 29.

59 A. Żaba-Branny, Franciszek Żaba, <http://krakow.gazeta.pl/krakow/1,53181,395 2629.html> (1 II 2015).

${ }^{60}$ W. Szura, Tarnowscy działacze łowieccy - inż. Franciszek Żaba, „Łowiec Tarnowski”, 2012, nr 2, s. 34

${ }^{61}$ F. F. Żaba, Gawędy..., s. 29.

${ }^{62}$ W. Szura, Tarnowscy działacze łowieccy - inż. Franciszek Żaba..., s. 34

63 Szeroko na temat stosunków towarzyskich rodziny Żabów: R. Żaba, Wspomnienia z lat ubiegtych..., oraz F. F. Żaba, Gawędy..., s. 28-41; nr 3, s. 31-41. 
ta nowego dworu w stylu klasycystycznym, oranżerii oraz oficyny uznaje się Piotra Aignera (1746-1841) ${ }^{64}$. Nie wiemy, czy w dworze istniało specjalnie wydzielone pomieszczenie na bibliotekę ${ }^{65}$.

Po nacjonalizacji majątku we dworze mieścił się dom dziecka. Obecnie ma w nim siedzibę specjalny ośrodek szkolno-wychowawczy, zajmujący się przygotowaniem zawodowym i rehabilitacją osób niepełnosprawnych m.in. przez hipoterapię. W 2013 r. potomkowie rodu Żabów (po latach procesów sądowych) odzyskali majątek w Zbylitowskiej Górze i planują odsprzedać go działającemu tu aktualnie ośrodkowi.

Całość dworskiej zabudowy otacza park o charakterze krajobrazowym, powstały z wcześniejszego założenia angielskiego z przełomu XVIII i XIX wieku, którego częścią był ogród francuski. Do majątku przynależał też las bukowy, w którym podczas drugiej wojny światowej hitlerowcy rozstrzelali od 8 do 10 tysięcy obywateli polskich.

Po nacjonalizacji majątek ruchomy właścicieli Zbylitowskiej Góry zabezpieczyli przedstawiciele ponownie powołanego do życia w $1945 \mathrm{r}$. Muzeum Ziemi Tarnowskiej. W skład przedmiotów zarekwirowanych weszło, oprócz licznych mebli, obrazów (np. portrety N. F. Żaby, S. Żaby, F. Moszczeńskiego) dwanaście oprawionych sztychów i biblioteka, składająca się z 1578 tomów oprawnych lub broszurowych, wraz z sześcioma szafami bibliotecznymi ${ }^{66}$ - jakkolwiek F. F. Żaba w swoich wspomnieniach wymienia liczbę pięciu tysięcy „książek oprawionych w skórę"67. Książki należące do Żabów wraz z innymi księgozbiorami podworskimi (m.in. Sanguszków) przekazano Bibliotece Muzeum Ziemi Tarnowskiej. Zwieziono je do tarnowskiego ratusza, gdzie spoczęły w bezładnych stosach. Później zostały posegregowane, zdezynfekowane i zinwentaryzowane. Zabezpieczone w dworach archiwalia przekazano Archiwum Państwowemu w Krakowie ${ }^{68}$.

${ }^{64}$ Piotr Aigner jest znany m.in. z takich budowli jak: Świątynia Sybilli w Puławach, pałac w Przeworsku, kościół św. Aleksandra w Warszawie, pałac w Igołomni. Aigner Christian Piotr, [w:] Larousse Encyklopedia Powszechna, t. 1: A-七, Warszawa 2002, s. 16.

${ }_{65}$ R. Żaba, Wspomnienia z lat ubiegłych..., s. 21.

${ }^{66}$ Archiwum Państwowe w Krakowie Oddział w Tarnowie (dalej skrót APwKOT), MOT 33/273/34, Spis przedmiotów sztuki zabezpieczonych w Zbylitowskiej Górze w dniu 2 lutego $1945 r$.

${ }^{67}$ Liczba podana przez F. F. Żabę (Gawędy..., s. 29) jest trudna do zweryfikowania ze względu na niezachowanie się inwentarza (nie wiadomo, czy w ogóle istniał!) oraz brak numeracji nadawanej przez właścicieli w obrębie zbioru. Duża rozbieżność w liczbach wymienionych w spisie z przejęcia majątku Żabów oraz podanych przez właściciela wymaga weryfikacji. Obecnie nie jest możliwe ze względu na brak źródeł archiwalnych.

68 M. Żychowska, Biblioteka Muzeum Ziemi Tarnowskiej, [w:] Muzeum Okręgowe w Tarnowie, pod red. Stanisława Potępy, [Tarnów] 1979, s. 37-38. 
Niezależnie od działań biblioteki Muzeum Ziemi Tarnowskiej po wojnie została reaktywowana Biblioteka im. Juliusza Słowackiego w Tarnowie, która w czasie działań wojennych utraciła ok. 45\% księgozbioru (przed wojną liczyła 28 tys. woluminów) ${ }^{69}$. Z uwagi na trudności organizacyjne zarząd Biblioteki im. Juliusza Słowackiego zwrócił się do Muzeum Ziemi Tarnowskiej o przejęcie resztek swego przedwojennego księgozbioru. W ten sposób 2 lipca 1945 r. obie instytucje złączyły swoje zbiory biblioteczne. Miejska Biblioteka Publiczna im. Juliusza Słowackiego oficjalnie rozpoczęła działalność dopiero 1 stycznia $1947 \mathrm{roku}^{70}$.

\section{Charakterystyka fragmentu księgozbioru Żabów z Zbylitowskiej Góry zachowanego w Miejskiej Bibliotece Publicznej}

W dokumentach dotyczących przejęcia majątku dworskiego Żabów w Zbylitowskiej Górze odnotowano 1578 tomów książek z biblioteki rodzinnej. Jednak ze względu na brak zachowanych archiwaliów rodzinnych (np. inwentarzy gospodarczych) nie można jednoznacznie uznać tej liczby za pewną ${ }^{71}$. W trakcie badań prowadzonych w latach 2013-2014 nad księgozbiorami podworskimi zachowanymi w MBP w Tarnowie do kolekcji ze Zbylitowskiej Góry udało się przyporządkować jeden stary druk, 366 książek dziewiętnastowiecznych i z pierwszej połowy XX wieku oraz trzy roczniki czasopisma „Przewodnik Naukowo-Literacki”. W inwentarzach MBP pochodzących z lat 1945-1950 widnieją informacje o dalszych 35 tomach, które do 2014 r. zostały ubytkowane lub powinny nadal znajdować się w bibliotece - wszelako nie udało się ich odnaleźć ${ }^{72}$. Co więcej, katalog książek Czytelni Naukowej wykazuje jeszcze dziewięć tytułów (w tym sześć dziewiętnastowiecznych w językach obcych). Niestety, i tych pozycji nie udało się odnaleźć w magazynie czytelni.

Najstarszy druk w kolekcji Żabów to Liebschaften König Augusts von Polen Karla von Pollnitz wydany w 1784 r. w Berlinie. Zarówno na okładce, jak i wewnątrz książki brak znaków proweniencyjnych typowych dla księgozbioru ze Zbylitowskiej Góry, jednak inwentarz starodruków, w któ-

${ }^{69}$ Z dziejów Miejskiej Biblioteki Publicznej im. J. Słowackiego w Tarnowie 19081968, pod red. B. Jaśkiewicza, Tarnów [1970], s. 59.

70 Tamże, s. 90.

71 F. F. Żaba w swoich wspomnieniach podaje liczbę ok. 5000 książek, ale wydaje się to mało prawdopodobne, przede wszystkim ze względu na brak wydzielonego pomieszczenia bibliotecznego i katalogu, co więcej przejęto tylko sześć szaf do przechowywania książek. F. F. Żaba, Gawędy..., s. 29; APwKOT, MOT 33/273/34, Spis przedmiotów sztuki zabezpieczonych w Zbylitowskiej Górze w dniu 2 lutego 1945 r.

${ }^{72}$ Inwentarze MBP w Tarnowie za lata 1945-1950, t. 1-3. 
rym zawarte są uwagi o pochodzeniu danej jednostki, wskazuje na własność Żabów ${ }^{73}$. Ponadto w starszym inwentarzu starych druków, który zaczął powstawać (choć nie został dokończony) przed podziałem księgozbiorów podworskich pomiędzy MBP w Tarnowie, Bibliotekę Jagiellońską oraz Bibliotekę Uniwersytetu Wrocławskiego, widnieje informacja o egzemplarzu Fascia coronata Wawrzyńca II Gembickiego wydanej w Krakowie ok. $1635 \mathrm{r}^{74}$ oraz Kazań niedzielnych wydanych w Wilnie w $1778 \mathrm{roku}^{75}$.

Zachowały się za to trzy roczniki „Przewodnika Naukowo-Literackiego” (dodatku do „Gazety Lwowskiej”) z lat 1884-1885 i 189176. Na egzemplarzach tych brak proweniencji typowej dla Żabów, jednak sposób oprawienia książki oraz adnotacja bibliotekarza zapisana ołówkiem na tomach wskazuje na księgozbiór ze Zbylitowskiej Góry.

Najliczniejszą grupę stanowią książki z lat 1851-1900, w sumie 273 woluminy, natomiast z pierwszej połowy XIX w. (1801-1850) odnotowano 73 tomy, a jedynie 20 pozycji wydanych po $1901 \mathrm{r}$. Pod względem językowym zachowany fragment jest nietypowy $\mathrm{w}$ porównaniu $\mathrm{z}$ innymi kolekcjami podworskimi zachowanymi w MBP w Tarnowie. W omawianym księgozbiorze aż 67\% stanowią książki w języku angielskim, 22\% w języku niemieckim, 6\% w języku francuskim i zaledwie 5\% książek w języku polskim. W pozostałych księgozbiorach język polski zdecydowanie przekracza 50\% wszystkich książek należących do danego rodu. Podobna tendencję dokumentują trzy pierwsze inwentarze MBP, spisane po drugiej wojnie światowej, w których odnotowywano jeszcze pochodzenie książek. Spośród 35 woluminów, które zostały ubytkowane, aż 27 to literatura w języku angielskim, pozostałe książki były w języku polskim ${ }^{77}$. Ze względu na znajomość języków obcych wśród członków rodziny Żabów ${ }^{78}$ oraz zamiłowanie do podróży i literatury pięknej (zbadany fragment zbioru wskazuje, że nie gromadzono na ogół polskich przekładów zagranicznych twórców) bardzo prawdopodobne jest, że właśnie książki obcojęzyczne były najczęściej kupowane przez Żabów. Taki charakter księgozbioru pasowałby do kosmopolitycznego trybu życia większości członków rodziny ${ }^{79}$.

O zamiłowaniu do literatury pięknej, znanym nie tylko ze wspomnień R. Żaby, świadczy też liczba zachowanych egzemplarzy - 328 wolumi-

73 Zob. Inwentarz Biblioteki Miejskiej Publicznej w Tarnowie, t. VIII, s. 2.

${ }^{74}$ Zob. Inwentarz Biblioteki Miejskiej Publicznej w Tarnowie (nieukończony), s. 25.

75 Tamże, s. 213.

76 Mowa o pozycjach oznaczonych sygnaturami: C-39969; C-39970; C-39976

77 Inwentarze MBP w Tarnowie za lata 1945-1950, t. 1-3.

78 Np. S. Żaba znał doskonale j. angielski, francuski, niemiecki, łacinę oraz grekę.

R. Żaba, Wspomnienia z lat ubiegtych..., s. 11.

79 F. F. Zaba, Gawędy..., s. 36. 
nów z 366 tomów całej kolekcji XIX i XX w. Poza tym odnajdujemy jeszcze książki z zakresu historii (15) oraz encyklopedie i słowniki (21), jak i np. książkę dla początkującego dzierżaw$\mathrm{cy}^{80}$, czy dzieło autorstwa N.F. Żaby The principal features of the history and literature of Poland $\mathrm{z} 1856 \mathrm{r}$. wydane w Londynie ${ }^{81}$. Według wspomnień F.F. Żaby w Zbylitowskiej Górze przechowywano też inne tytuły napisane przez protoplastę rodziny ${ }^{82}$.

Najwięcej zakupiono książek wydanych w Lipsku (232 tytuły), głównie z serii "Collection of British Authors” B. Tauhnitza oraz $\mathrm{z}$ wydawnictw P. Reclama i F. A. Brockhaus'a. Zdecydowanie mniej licznie są reprezentowane inne duże ośrodki wydawnicze, takie jak Londyn (39 wol.) i Paryż (27)

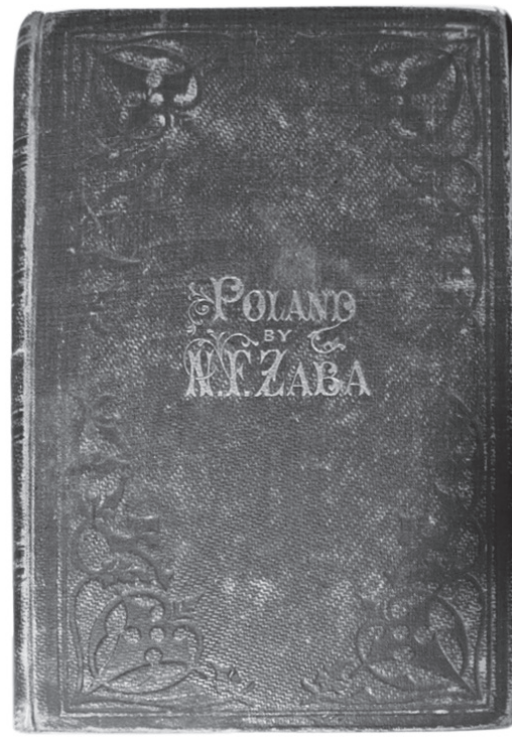

Fot. 1. Okładka The Principal Features of the History and Literature of Poland autorstwa N. F. Żaby (MBP w Tarnowie, sygn: C-35960). oraz Edinburgh (24). Natomiast z polskich ośrodków najwięcej książek zakupiono w Lwowie - sześć tytułów. Z serii wydawniczych, oprócz już wspomnianej powyżej, znalazły się m.in.: „Biblioteka Pisarzy Polskich” F. A. Brockhausa, czy „Collection of ancient and modern British Authors” z oficyny Baudry'go w Paryżu.

W zachowanej kolekcji nie natrafiono na książki w oprawach broszurowych, a wszystkie egzemplarze posiadają introligatorską oprawę wydawniczą lub oprawy na zamówienie Żabów. Wśród książek wydanych do 1860 r. znajdują się tytuły oprawione w wyszukany sposób i najprawdopodobniej pochodzace ze szkockich i angielskich pracowni. Solidnie wykonane oprawy posiadają bogato zdobione grzbiety z tłoczeniami złotem, wzorami geometrycznymi oraz nazwiskiem autora i tytułem. Estetykę oprawy podkreślają wyklejki (z zadrukowanego w fantazyjne wzory papieru) zdobiące wewnętrzne strony okładek. Po osiedleniu się w Zbylitowskiej Górze Żabowie korzystali z usług introligatorów z lokalnych

${ }^{80}$ Dzierżawca poczatkujacy jako zupetne wedlug postępu rolnictwa opracowanie Dzierżawcy poczatkujacego przez Pana Szne, wyd. 2 z dodatkiem o chmielu, Toruń 1862, MBP w Tarnowie, sygn: C-90213

${ }_{81}$ N. F. Żaba, The Principal Features of the History and Literature of Poland, London 1856, MBP w Tarnowie, sygn: C-35960.

${ }^{82}$ F. F. Żaba, Gawędy..., s. 33. 

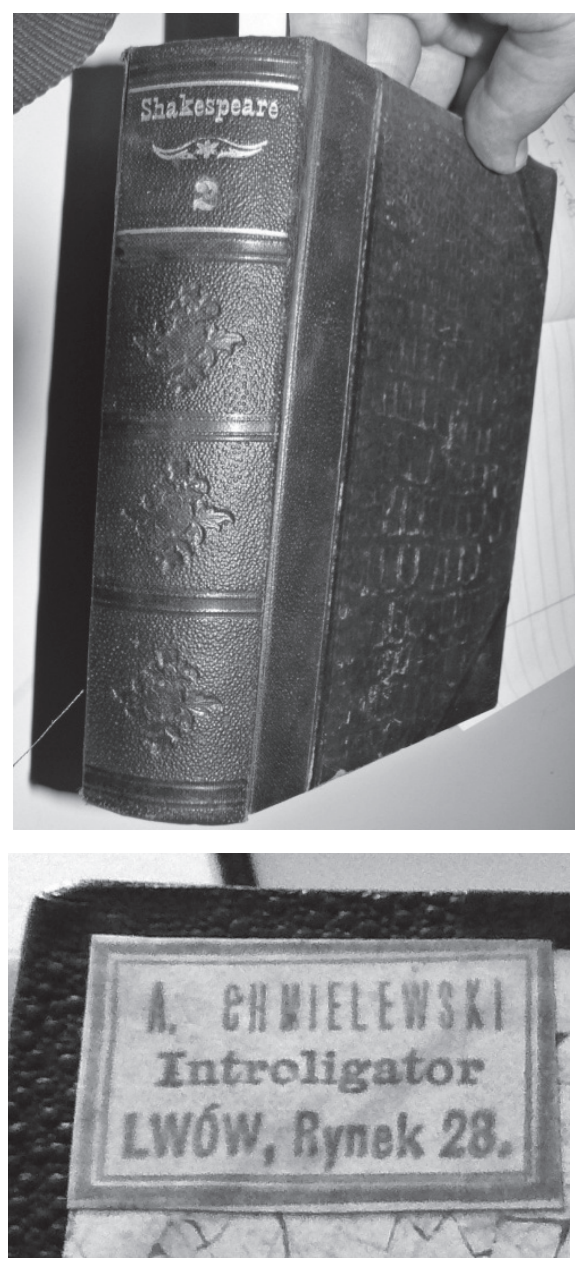

Fot. 2. Okładka i naklejka firmowa A. Chmielewskiego, który wykonał większość opraw dla książek w języku angielskim (MBP w Tarnowie, sygn: A-90554).

ośrodków. Oprawy przez nich wykonane były skromniejsze, płócienne lub w półskórek - tekturowe w kolorach: zieleni, czerwieni, musztardowej żółci, brązu, granatu i czerni. Na grzbietach tłoczono nazwisko autora, tytuł (lub tytuły w przypadku klocków introligatorskich) oraz numery tomów. Na kilku egzemplarzach książek anglo- i francuskojęzycznych widnieje naklejka lwowskiego introligatora Andrzeja Chmielewskiego ${ }^{83}$. Większość woluminów ozdobiono dodatkowo barwieniem brzegów stron.

W kolekcji można zauważyć ciekawe oprawy wydawnicze: angielskie, francuskie i niemieckie zXIX w. i pierwszej połowy wieku XX, reprezentujące popularne $\mathrm{w}$ danym okresie trendy w przemyśle wydawniczym. Na ogół są to oprawy płócienno-tekturowe $\mathrm{z}$ tłoczeniami w kalejdoskopowe wzory czy też imitującymi podobizny autorów, barwionymi np. na złoto. Inne oprawy posiadają rysunki roślin lub postaci ludzkich nawiązujących do treści książki.

Swego rodzaju ciekawostką są bez watpienia zachowane na egzemplarzach nie tylko naklejki introligatorskie, ale i naklejki księgarzy i antykwariuszy czy też ich pieczęcie. Wśród nich można odnotować takie firmy, jak np.: lwowskie „Gubrynowicz \& Schmidt”, „Ch. Wild”, „Seyfarth \& Czajkowski” oraz zagraniczne - „Caesar Fritsch”, „Blackie and Son”, „Gilhofer \& Ranschburg”.

${ }^{83}$ Andrzej Chmielewski (1830-1903) introligator lwowski, powstaniec styczniowy - Kronika, „Gazeta Lwowska”, 1903, nr 213, s. 4. 
Najbardziej charakterystyczną cechą kolekcji Żabów jest sposób znakowaniaksiążek. Oznaczenie własności (znaki proweniencyjne) pozwala określić przynależność książki do danego właściciela, jak i prześledzić jej losy i zmiany formy znakowania ${ }^{84}$. Pierwszy znak proweniencyjny stanowił naklejany na wyklejce papierowy ekslibris z czarno-białym herbem Kościesza-Żaba (odnotowano 92 pozycje). Brak jest informacji o autorze ekslibrisu i ośrodku, w którym był wykonany. Najprawdopodobniej pomysłodawcą był N. F. Żaba, ponieważ pojawia się on już na książkach należących do jego żony Anny $\mathrm{z}$ d. MacLeod.

Drugim sposobem znakowania były pieczęcie (w sumie odbite na 149 pozycjach) o różnej treści i kształtach, które zapewne używane były również do uwierzytelniania dokumentów i korespondencji. Wśród nich znalazły się dwa typy pieczęci osobistej: pierwsza należąca do S. Żaby i przedstawiająca skrót S.K.Z. z koroną i ramieniem trzymającym szable; na drugiej - należącej

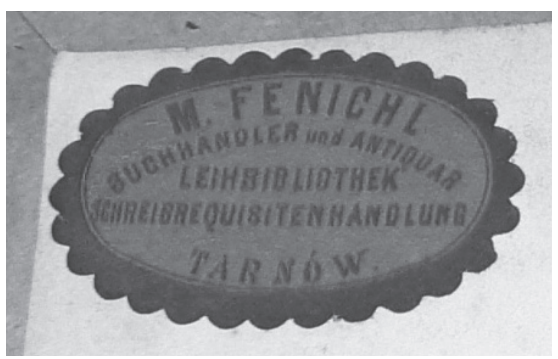

Fot. 3. Naklejka firmowa księgarza i antykwariusza tarnowskiego M. Fenichla (MBP w Tarnowie, sygn: N-53527).

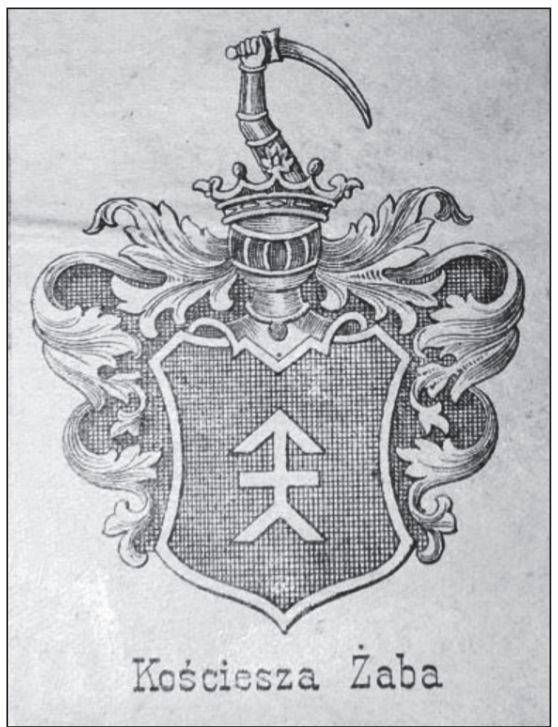

Fot. 4. Ekslibris Kościesza-Żaba (MBP w Tarnowie, sygn: A-56524). do ostatniego właściciela majątku, syna gen. R. Żaby - widniała informacja: „Zarząd gospodarstwa rolnego Franciszka Żaby w Zbylitowskiej Górze p. Tarnów". Ponadto warto zwrócić uwagę na niewielką pieczęć herbową Kościesza Żaba, którą tłoczono na ślepo na stronie tytułowej. Najprawdopodobniej znak ten powstawał za pomocną sygnetu rodowego ${ }^{85}$.

${ }^{84}$ Co się tyczy badań proweniencyjnych, por. M. Sipayłło, O metodzie badań proweniencyjnych starych druków, „Z Badań na Polskimi Księgozbiorami Historycznymi”, 1:1975, s. 10.

${ }^{85}$ Sygnet ten został zakupiony przez J. P. Szeligę w latach siedemdziesiątych XX w. w Pilźnie koło Tarnowa od osoby prywatnej. Brak informacji o wcześniejszych losach zabytku, można jednak przypuszczać, że należał on wcześniej do rodu Żabów. Informacja na podstawie korespondencji z J. P. Szeligą z dnia 10 II 2014 r. 

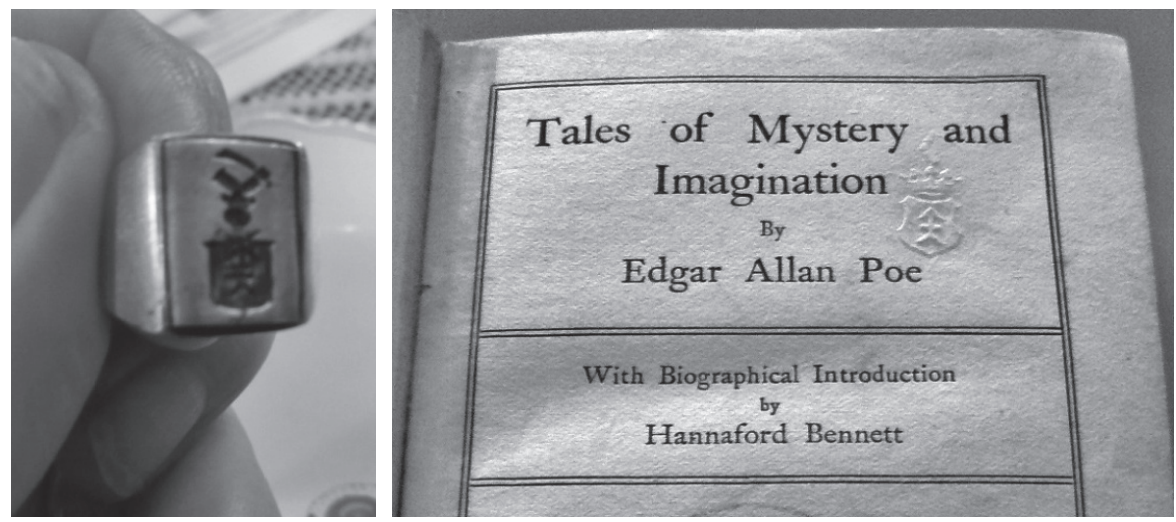

Fot. 5. i 6. Po lewej: Sygnet z herbem Kościesza będący obecnie własnością J. P. Szeliga ${ }^{85}$. Źródło: http://myvimu.com/exhibit/47373217-herb-kosciesza-odmiana-herbowa-sygnet] Po prawej - odcisk przedstawiający herb Żabów (MBP w Tarnowie, sygn: A-13940).

Uzupełnieniem wspomnianych znaków były też spotykane podpisy oraz dedykacje - w sumie 93 różne podpisy, w tym osiem dedykacji pozostawionych na książkach zarówno przez członków rodziny, jak i osoby z kręgu towarzyskiego Żabów, np. Stanisława Sożańskiego czy Oswalda Morawskiego. Wśród dedykacji uwagę zwraca napisana w języku angielskim przez Izabelę Axentowicz ${ }^{86}$ dla E. Żaby ${ }^{87}$. Najliczniej reprezentowane są książki z podpisem S. Żaby - 22 przykłady oraz jego matki, A. Żaby. Inni członkowie rodu zostawili od pięciu do zaledwie jednego podpisu. Brak wśród proweniencji podpisów córek Stanisława oraz żony gen. R. Żaby czy żony jego syna Franciszka. 16 razy pojawia się podpis „Żaba” bez inicjałów. Niektóre książki posiadają równocześnie kilka znaków proweniencyjnych, np. ekslibris, podpis i jeden z rodzajów pieczęci.

Wśród książek, na których widnieją znaki proweniencyjne osób spoza rodziny, na szczególną uwagę zasługują dwie pozycje, które pierwotnie należały do Władysława Wszelaczyńskiego ${ }^{88}$ - o czym świadczy jego pieczęć z imieniem i nazwiskiem oraz umieszczony na tyl-

${ }^{86}$ Izabela Axentowicz była żoną Teodora Axentowicza, znanego polskiego malarza, grafika, profesora i rektora Akademii Sztuk Pięknych w Krakowie. Co się tyczy stosunków towarzyskich Żabów, zob. R. Żaba, Wspomnienia z lat ubiegtych..., s. 10.

87 Mowa o Ralph Waldo Emerson, Essays, Leipzig 1915, MBP w Tarnowie, sygn: A-14366.

${ }^{88}$ Władysław Wszelaczyński (1847-1896) - polski pianista i kompozytor, założyciel Towarzystwa Muzycznego w Tarnopolu - był także zbieraczem starodruków i rękopisów z XVI i XVII w. oraz kolekcjonerem pamiątek związanych z Fryderykiem Chopinem. 


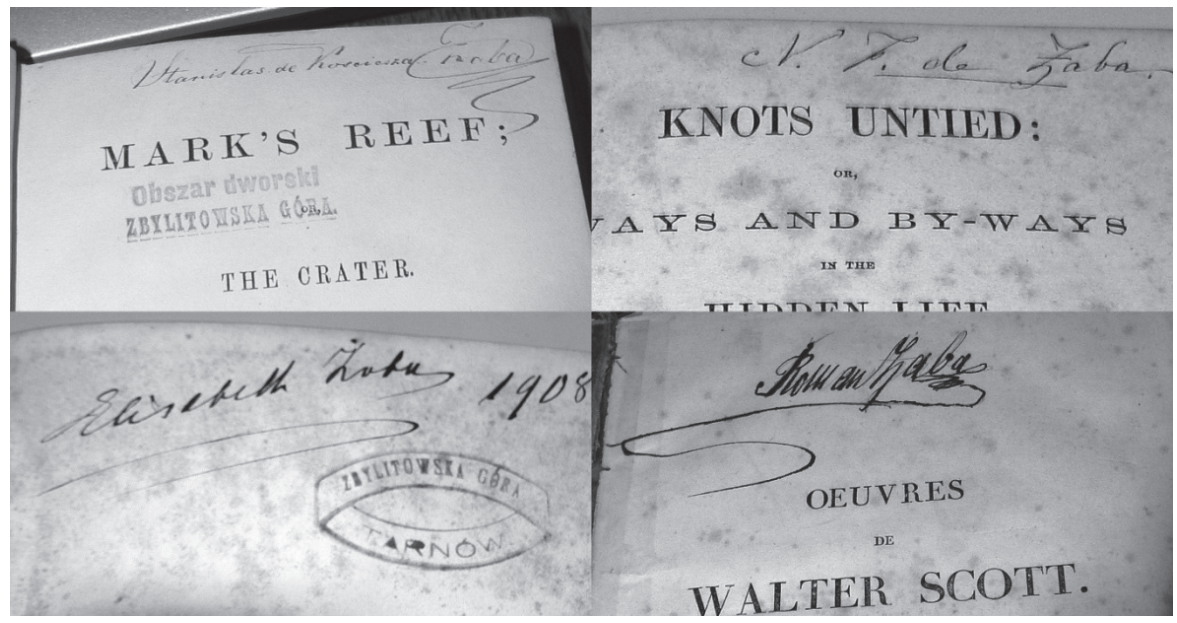

Fot. 7. Przykładowe podpisy (od lewego górnego rogu): S. Żaby, N. F. Żaby, E. Żaby i R. Żaby oraz przykłady pieczęci używanych do znakowania książek (MBP w Tarnowie, sygn: A-13917, A-57533, A-56537, F-54750).

niej wyklejce papierowy ekslibris ${ }^{89}$. Takie same znaki proweniencyjne W. Wszelaczyńskiego widnieją na książce z kolekcji książąt Sanguszków ${ }^{90}$. Książki te posiadają też adnotacje późniejszych właścicieli po 1900 r. o wprowadzeniu ich do własnych księgozbiorów. Również warto wspomnieć o książce autorstwa Fredericka Marryata ${ }^{91} \mathrm{z}$ podpisem gen. Romana Sołtyka ${ }^{92}$.

Obok znaków proweniencyjnych w wybranych książkach można znaleźć zapiski czytelnicze, dokonywane bezpośrednio na stronnicach książek lub na luźnych kartkach papieru. Ciekawy przykład zapisków w postaci poprawek w tekście znalazł się w Złotej księdze szlachty polskiej T. Żychlińskiego ${ }^{93}$. Zapiski te najprawdopodobniej zostawili bracia Franciszek i Roman Żabowie, na co wskazywałyby charaktery pisma.

Oceniając kolekcję nie tylko pod kątem znaczenia dla historii regionu tarnowskiego, lecz także pod względem unikalności samych wydań

89 E. Borel, Album Lyrique de la france moderne, Stuttgart [b. r.], MBP w Tarnowie, sygn: F-54702.

${ }_{90}$ Mowa o pracy K. Szajnochy, Szkice historyczne, t. 1, wyd. 2, Lwów 1858 (MBP w Tarnowie, sygn: Mag.-178471). A-13735).

92 Roman Sołtyk (1822-1873) - gen. major austriackiej kawalerii, huzar, adiutant przyboczny cesarza Franciszka Józefa I - był ojcem chrzestnym R. Żaby (R. Żaba, Wspomnienia z lat ubiegtych..., s. 11).

93 T. Żychliński, Złota księga szlachty polskiej, R. 6, Poznań 1884, s. 455 (MBP w Tarnowie, sygn: B-5892). 


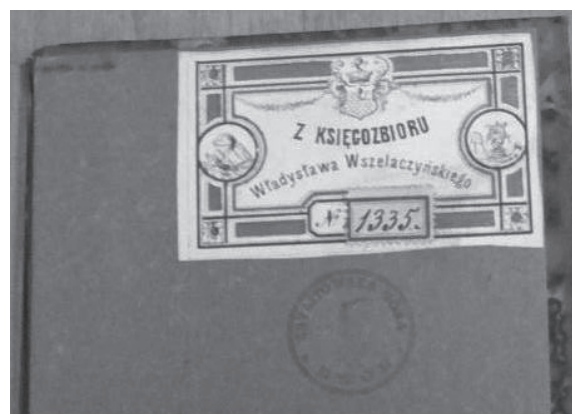

Fot. 8. Ekslibris W. Wszelaczyńskiego oraz jedna z pieczęci Żabów (MBP w Tarnowie, sygn: F-54702).

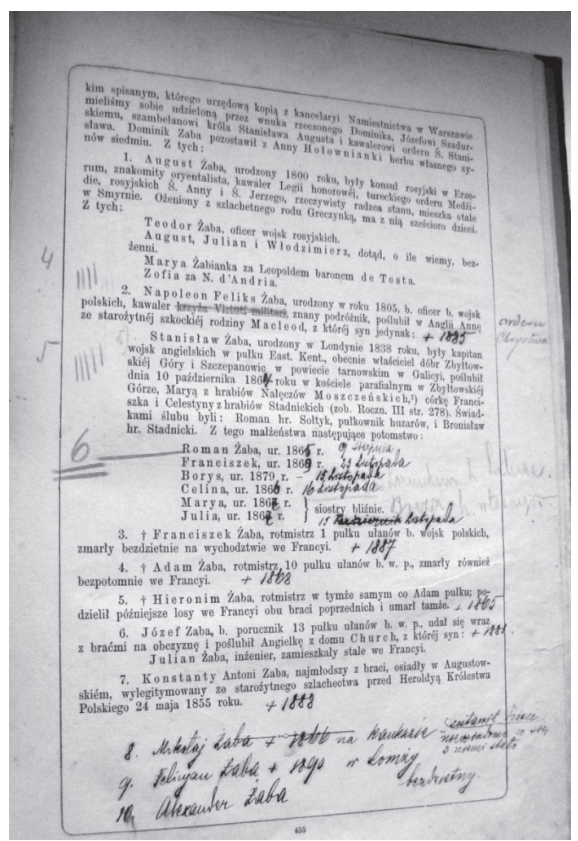

Fot. 9. Zapiski genealogiczne: tekst piórem - F. Żaba, uzupełnienia naniesione kolorową kredką - R. Żaba (MBP w Tarnowie, sygn: B-5892). poszczególnych książek, można (dzięki porównaniu np. z bazami KARO, NUKAT) zauważyć, że aż 107 tytułów książek pochodzących ze Zbylitowskiej Góry nie występuję $\mathrm{w}$ innych polskich bibliotekach, a 45 wydań jest dostępnych tylko w niektórych placówkach ${ }^{94}$. Na ogół są to tytuły anglo- i niemieckojęzyczne.

Nasuwa się w tym miejscu wniosek, że ze względu na unikatowość kolekcji przechowywanej w MBP w Tarnowie placówka powinna postarać się o ukończenie katalogowania książek wchodzących w jej skład oraz zadbać o przechowywanie ich w najlepszych możliwych w obecnej sytuacji lokalowej książnicy warunkach. W przyszłości, jeśli zostana pozyskane odpowiednie środki, warto fragmenty zachowanej kolekcji Żabów poddać procesowi digitalizacji.

Obecnie kolekcja Żabów, podobnie jak i inne książki podworskie, są wykorzystywane zarówno przez pracowników biblioteki, np. podczas tworzenia wystaw tematycznych, prowadzenia lekcji bibliotecznych, ale i przez czytelników, którzy w oparciu o nie piszą prace naukowe czy wykorzystuja informacje $\mathrm{np}$. $\mathrm{z}$ prasy dziewiętnastowiecznej $\mathrm{w}$ amatorskich badaniach historyczno-genealogicznych. Księgozbiór Żabów, jak i inne kolekcje podworskie w MBP w Tarnowie, moga posłużyć do powstania ciekawych prac z zakresu historii lub lite-

${ }^{94}$ Naturalnie istnieje możliwość, że dana placówka nie ukończyła katalogowania zbiorów starszych, przez co przedstawione liczby mogą ulec zmianie. 
raturoznawstwa. Mogą także być wykorzystywane np. przy omawianiu konkretnych serii wydawniczych, edycji dzieł danego autora lub opraw tak wydawniczych, jak i zamawianych przez właścicieli księgozbioru. Dostępne w MBP pozycje stanowią też źródło do badań nad lokalnym rynkiem usług wydawniczych i introligatorskich - nie brak bowiem wśród nich tytułów wydanych w Tarnowie czy sprzedawanych i oprawianych u lokalnych właścicieli firm, o czym świadczą zachowane pieczęcie i naklejki firmowe. Możliwości jest wiele i warto je przedstawić szerszemu gronu zainteresowanych bibliofilstwem, galicyjskim rynkiem książki oraz lokalnym historykom amatorom, jak i przedstawicielom ośrodków akademickich w naszym rejonie.

Streszczenie

\section{Księgozbiór rodziny Żabów ze Zbylitowskiej Góry w zbiorach Miejskiej Biblioteki Publicznej im. Juliusza Słowackiego w Tarnowie}

Do 1945 r. ziemię tarnowską zamieszkiwały liczne rody ziemiańskie. Wśród nich warto zaznaczyć przedstawicieli rodziny Żabów herbu Kościesza: Napoleona Feliksa Żabę (1805-1885) - powstańca listopadowego, działacza politycznego na emigracji, podróżnika i poetę, Stanisława Żabę (1838-1919) - podporucznika angielskiego, członka licznych klubów angielskich oraz działacza społecznego na terenie Galicji, Romana Żabę (1864-1945) - pułkownika Cesarskiej i Królewskiej Armii Austro-Wegierskiej, a następnie generała Wojska Polskiego i działacza społecznego, oraz Franciszka Feliksa Żabę (1906-1982) - inżyniera w Zakładach Azotowych w Tarnowie, oficera AK.

Właściciele Zbylitowskiej Góry zgromadzili w swoim dworze ciekawy księgozbiór, którego fragment przechowuje od reformy rolnej w 1945 r. Miejska Biblioteka Publiczna im. Juliusza Słowackiego w Tarnowie. W kolekcji tej dominuje literatura piękna, głównie w języku angielskim. Ponadto w kolekcji występują licznie książki wydawane w seriach lub wydawnictwach wielotomowych. Książki posiadają różnego typu oprawy wykonane na zamówienie oraz ciekawe oprawy wydawnicze polskie i zagraniczne. W kolekcji znalazły się liczne znaki proweniencyjne: eksibrisy, pieczęcie i podpisy odręczne, jak i dedykacje. W zachowanym fragmencie księgozbioru z Zbylitowskiej Góry znajdują się unikatowe wydania, posiadające ciekawe znaki introligatorskie, księgarskie i antykwaryczne, dostępne w nielicznych ośrodkach w Polsce. Z tego powodu kolekcja ma znaczenie nie tylko dla historii regionu tarnowskiego, ale jest cennym dziedzictwem narodowym. 
Slowa kluczowe: badania proweniencyjne - biblioteki prywatne XIX i XX w. Miejska Biblioteka Publiczna im. Juliusza Słowackiego w Tarnowie.

Summary

\section{Books from the Żaba of Zbylitowska Góra family library in the collections of the Juliusz Słowacki Municipal Public Library in Tarnów}

Prior to 1945, Tarnów region was homeland to numerous landowning families, among whom the Żaba clan of the Kościesza coat of arms played a prominent role, with its leading representatives: Napoleon Feliks Żaba (1805-1885) - participant of the November Uprising, emigre politician, traveller and poet; Stanisław Żaba (1838-1919) - second lieutenant in the British army, member of numerous English clubs, and social activist in his native country; Roman Żaba (1864-1945) - colonel in the Austro-Hungarian army and general in revived Polish armed forces; Franciszek Feliks Żaba (1906-1982) - engineer at the Nitric Chemistry Plant in Tarnów and officer of the Home Army during World War II.

The owners of Zbylitowska Góra gathered in their manor house an interesting book collection, a fragment of which, after the land reform of 1945, was appropriated by the Juliusz Słowacki Municipal Public Library in Tarnów. In its present state, the collection is dominated by English works of fiction, published in various series and multivolume sets. These books are bound in different types of bindings, provided by the publisher as well as ordered from artisans in Poland and abroad. The books bear numerous provenance marks: book plates, stamps, signatures, and dedications. The extant fragment of the original collection from Zbylitowska Góra encompasses rare editions with interesting bookbinder, bookseller, and antique shop signs, which are uncommon in Polish libraries. Due to this, the collection is of importance not only to the Tarnów region, but also to the whole country.

Key words: provenance research - private libraries in the $19^{\text {th }}$ and $20^{\text {th }}$ c. J. Słowacki Municipal Public Library in Tarnów. 